Discourse and Communication for Sustainable Education, vol. 6, pp. 50-71, 2015

\title{
Evaluation, Support and Promotion of Specialists' Competitiveness Development in Modern Enterprise as Learning Organization
}

\author{
Irena Katane \\ Latvia University of Agriculture, Latvia \\ Ineta Kristovska \\ University College of Economics and Culture, Latvia \\ Gita Vjatere \\ Insurance Corporation "Balta" in Latvia, Latvia \\ Edgars Katans \\ University College of Economics and Culture, Latvia
}

\begin{abstract}
The process of globalization and the changeability of environment nowadays demand that society ensure sustainability for itself and its lifewide environment. Therefore nowadays the paradigm of personality's and specialist's competitiveness is changing. The old paradigm is substituted by a set of new viewpoints and concepts. The issue of ensuring the environment fostering the development of specialists competitiveness in the modern enterprise becomes even more important. Research in this sphere had three stages: 1) development of theoretically-methodological base for specialists' competitiveness research; 2) diagnostics and evaluation of the specialists' competitiveness in modern insurance enterprise (experimental approbation of the competitiveness research methodology); 3) development, evaluation, improvement of "The Model for Evaluation, Support and Promotion of the Staff's Competitiveness Development in Modern Enterprise as Learning Organization" and its offer for implementation into research base - insurance enterprise. The objectives of research: 1) to investigate the specialists' competitiveness in the modern insurance enterprise; 2) to develop and evaluate The Model for Evaluation, Support and Promotion of the Specialists's Competitiveness Development in Modern Enterprise as Learning Organization in the contexts of information and knowledge society and sustainable development.
\end{abstract}

Keywords: Information and knowledge society, modern enterprise as learning organisation, specialists' competitiveness, sustainable development 


\section{Introduction}

The dynamics of socio-economic activities update research of human competitiveness in the new context - in the context of sustainable development. Many processes make us question the possibilities of sustainable development and aims of activity. The imperative of today is the sustainable development, including balanced development of the human lifewide environment which has various contexts, for example, economic, natural and social environment contexts.

Club of Rome: Aurellio Peccei the founder of this global non-governmental organization of scientists, emphasized that the search for the model of the world's developmental management should be based on the idea that an individual must learn to manage him/ herself. The self-regulation should be conscious, comprehended and target-oriented. Peccei indicates that an individual is in dilemma: either to change as a personality under the changeable environment (..), or to be doomed (cited in Gnazzo, 2007).

The ecological paradigm and synergetic paradigm as new transdisciplinary and interdisciplinary paradigms enable to study an individual as a self-developing, self-organizing and self-evaluating system that functions in the lifewide environment, learns to live, plan and forecast; constructs and gathers its own experience; that is able to choose and to be responsible for the consequences of its own actions under the conditions of modern rapidly changing environment. The ecological and synergetic approaches enable to draw the conclusion that nowadays an individual must learn to live and change in while interaction in this changeable environment.

As a result competitiveness has become one of the basic categories not only in economics but also in education sciences. Moreover, personality is defined possessing the ability to become a competitive and respectable personality and a marketable specialist due to characteristic features and competencies acquired during life. It is important to be aware and get deeper understanding of the new meaning of the competitiveness concept which is totally different from the old paradigm of competitiveness and the stereotypes connected with it. All over the world, researchers (Apressyan, 1997; Bevan et al., 1997; Covey, 1990; Floren, 1998; Gold et al., 1997; Hansen, 1998; Trunk Širca et al., 2006; Андреев, 2006; Митина, 2003; Шаповалов, 2005; Широбоков, 2000; etc.) work out substantiations of the concepts - personality's competitiveness and specialist's competitiveness within the new paradigm of competitiveness and write about new approaches and principles in contemporary education and business activities in modern society.

It is necessary to create the support system in modern enterprise as learning organization, which would promote the specialist's competitiveness development.

\section{Research Methodology}

There are three stages to our research: 1) development of theoretically-methodological base for specialists' competitiveness research; 2) diagnostics and evaluation of the specialists' competitiveness in modern insurance enterprise (experimental approbation of the competitiveness research methodology); 3) development, evaluation, improvement of "The Model for Evaluation, Support and Promotion of the Staff's Competitiveness Development in Modern Enterprise as Learning Organization” and its offer for implementation into research base - insurance enterprise. 
The objectives of research: 1) to investigate the specialists' competitiveness in the modern insurance enterprise; 2) to develop and evaluate The Model for Evaluation, Support and Promotion of the Specialists's Competitiveness Development in Modern Enterprise as Learning Organization in the contexts of information and knowledge society and sustainable development.

The collection research methods used here are analysis and evaluation of scientific literature, a questionnaire, modeling, expertise, performing mathematical processing of data, including Friedman Test using SPSS 19.0 software.

\section{Research Results}

\section{Results of the 1 st research stage}

In order to diagnose and evaluate, support and promote the development of specialist's competitiveness in an enterprise, in the beginning it is important to answer the following questions:

What is competitiveness? What is the methodological basis for evaluation of specialists' competitiveness in modern enterprise?

Answer to these questions can be given studying results of research performed in the field of concurrentology, including substantiation of the concepts: personality's competitiveness and specialist's competitiveness (Apressyan, 1997; Floren, 1998; Gold et al, 1997; Li, 2011; Андреев, 2006; Митина, 2003; Шаповалов, 2005; Широбоков, 2000 etc.).

According to Mitina (Митина, 2003), historically the concept of competitiveness was attributed to the antagonistic struggle of entrepreneurs, manufacturers on the conditions more favorable for their entrepreneurship, production and marketing in order they could gain more profit. Mitina, continuing on her idea, points out that, alongside with the economic competition, it is possible to discuss the biological competition, namely, when such active interaction develops between the representatives of one or different species, which has the nature of competition in order the representatives could survive and reproduce.

Many USA specialists of economics find that competitiveness consists of two parts: 1) maintenance of continuously increasing standards of living; 2) maintain of leading positions in the economy of global scale. The committee of the USA president, dealing with the issues of competitiveness in the field of production, has provided its definition for competitiveness: it is an ability to produce goods and render services, which are sold at the international markets, at the same time maintaining and increasing the standards of living, which are the same as the competitors have or even higher (cited from Митина, 2003).

In the old paradigm, the competitiveness more often is related to the personality's success and victories over its competitor, sometimes it is related to an image of a harsh fighter, who has no mercy towards the enemy, competitor and who considers any means useful for achieving the goals. It is possible to draw the following conclusions from the substantiation of the new paradigm of competitiveness: crisis shall be attributed to all, even to the most successful entrepreneurs, the most advanced society and economy; however, to be competitive means to be able to adapt to new conditions, to overcome difficulties and to achieve more than before - before the crisis. In the new paradigm the 
ability to change, to live and to develop in the changeable environment is particularly important. The development of an entrepreneur's (business leaders') competitiveness nowadays is related not only to the features characteristic to a leader, but, first of all, to the socio-psychological and moral characterizing indicators, the interaction of a personality with society, attitude towards other people, oneself, duties, moral and ethical values. There are three spheres of the development of a specialist's competitiveness: 1) activity sphere; 2 ) the sphere of interaction with the environment, including the interaction with social environment - other people; 3 ) the sphere of a personality's selfdevelopment, including the self-awareness and self-determination (Katane, 2010).

In order to perform the comparative analysis of old and new paradigms of competitiveness, several scientists use the metaphors of a shark and a dolphin (Apressyan, 1997). Using metaphors, it is possible to draw a conclusion that, within the context of the old paradigm of competitiveness, a competitive personality could be compared to an image of a shark, which, in the process of achieving its goal, is able "to swallow" anybody standing in its way. This image of a competitive personality has grown old. It is the insight and totality of views, possessed by previous generations of mankind concerning a competitive personality, based on the insight into biological competition.

Now is the time, when a new paradigm of competitiveness is born that makes us radically change our views concerning the competitive personality, which could be symbolically compared with a dolphin. It is a person, able to co-operate, to help others, perceiving his/her competitors as his/her potential partner for co-operation. This person is able to maintain the balance between I-ego and I-eco in his/her thinking and actions. Dolphintype competitive personality can be a leader and at the same time also a member of a team, working together with others and co-operating with them. In the context of the new paradigm, a competitive personality in the process of its development, instead of competing with others, its competitors, competes with itself - it combats its bad habits, shortcomings, disability and unwillingness to perform something important or necessary to do. It is a determined personality, possessing clear goals for future. The competitive personality of the new type is creative and flexible in its thinking and actions; therefore it is able to deal with the problems in the unusual, nonstandard situations. It is able to take decisions and to be responsible, and it is a personality one can rely on and to whom one can trust. Such a person is respected by others and he/she respects himself/herself. Such a person is welcomed among friends and acquaintances, and he/she is demanded in the professional field. Not only success indicates competitiveness, rather an ability to overcome crises, finding inner potential and opportunities for the development in own lifewide environment, including the professional environment and labour market, as well as discovering development perspectives in future. As a result of the above mentioned, the concept competitiveness becomes more and more important in the science of pedagogy. Competitiveness becomes a scientific category of pedagogy (Katane, 2010; Katane, 2011; Katane \& Kalnina, 2010).

It is proved by the fact that in the end of the $20^{\text {th }}$ century and in the early $21^{\text {st }}$ century Russian academician Andreyev (Андреев, 2006) implemented a new concept - concurrentology - and characterized it as the interdisciplinar research trend in social sciences, including education sciences, on an individual's/personality's competitiveness.

It is possible to observe two tendencies in the substantiation of a specialists' competitiveness. 
- Scientists of economics and other disciplines, on the basis of regularities, categories, conceptions, theories of economics, try to use transfers for the development of the definitions of a specialist's competitiveness.

For example, Garafutdinova (Гарафутдинова, 1998) and Tarakanova (Тараканова, 2004) separately and independently in their publications have substantiated the structure and indications of the individual's/person's competitiveness. Both authors write that the definition of the competitiveness of goods should be used to define the individual's marketability. They write that the marketability of goods is determined by the totality of qualities, which enables to identify the advantageous difference of goods in comparison with other goods. The totality of the marketability qualities of goods consists of three groups of elements: the technical, economical, as well as social and organizational indicators.

- The representatives of pedagogy and psychology sciences develop the substantiation of a personality's competitiveness and/or a specialist's competitiveness on the basis of humanistic and ecological approach in education.

For example, Russian scientists Mitina (Митина, 2003) and Shirobokov (Широбоков, 2000) write regarding the context of the aims of teacher education nowadays that a teacher is a competitive person, if this person is a marketable specialist in the labour market, who is able to self-actualize under the changeable social, including labour environment conditions of a particular profession.

In both cases, the competitiveness of a specialist is related to his marketability and employability in the labor market.

After theoretical research we can offer the definition of competitiveness concept. Competitiveness is an integrative totality of an individual's qualities (qualities of a personality and a specialist) that ensures its viability, including development and self-actualization, under the conditions of changing environment. The competitive personality is characterized by the following qualities/features: 1) the characterizing indicators of a personality orientation and self-conception, including determination and action oriented towards success; the readiness to overcome difficulties and take a risk; persistence, adequate self-assessment and daring to take a risk; 2) well-developed self-regulation, including volition, stress endurance, self-reflection, including analytical-evaluating and systemic thinking; personality's flexibility (flexibility in thinking, emotional sphere, behaviour), the ability to make a decision; the responsibility for the made decisions and their consequences; 3 ) different competences, including professional competences and creativity as an ability, oneself- (ego-) and environment- (eco-) oriented friendly thinking, attitude and behaviour: observation of moral and ethical principles, the principles of environmental, including social environment (community), balance and sustainability, readiness for the co-operation with other people; 4) readiness to change oneself in order to maintain the balance with the changing environment, readiness to start changes in the environment on the basis of environment-friendly attitude and action.

In order it would be possible to study, diagnose and evaluate the competitiveness of research base enterprise specialists, it was necessary to have research methodology.

For this purpose Katane (Senior Researcher and Assoc. Professor, Institute of Education and Home Economics at Latvia University of Agriculture) elaborated methodology for the evaluation of a specialist's competitiveness, which was grounded on the results of previously performed studies (Katane, 2010; Katane, 2011; Katana \& Kalnina, 2010) 
and which, in collaboration with Vjatere (maiden name Katana) and Kristovska (ViceRector of University College of Economics and Culture), was approbated within the pilot research at one of the Latvian insurance enterprises (Katane \& Kristovska, 2015a; Katane \& Kristovska, 2015b; Katane, Kristovska \& Katana, 2013).

The authors of this article studied the competitiveness evaluation methodology, developed by several researchers (Dimitrova, 2013; Li, 2011; Otola, Ostraszewska \& Tylec, 2013; Митина, 2003; Гриншпун, 2009; Житлухина \& Алямовская, 2015; Фетискин, Козлов \& Мануйлов, 2002; Тамарская \& Власова, 2002; etc.). Results of this investigation became the methodological basis for the evaluation of specialist's competitiveness in modern enterprise (Katane, 2010; Katane, 2011; Katane \& Kristovska, 2015a; Katane \& Kristovska, 2015b).

There are several approaches for developing research methodology of competitiveness in education sciences: 1) functional approach-competitiveness is substantiated by describing the manifestations of personality's competitiveness, as well as readiness for various actions, including interaction with the external environment; 2) biometrical approach-competitiveness is characterized as a totality of personality's several qualities (individual features, competencies, other qualities), where these qualities serve as the indicators of competitiveness; 3) structural approach - there is a structural model of competitiveness provided, emphasizing several components.

Based on the competitiveness structure model (Figure 1) I. Katane formulated indicators of specialists' competitiveness. She respected all three approaches: structural, biometrical and functional approach. The system for the evaluation of specialists' competitiveness consists of 66 indicators. The methodology elaborated and applied for the research aim comprises not only the system of indicators for the evaluation of competitiveness, but also a questionnaire developed in conformity with it, as well as the methodology for the determination of a specialist's competitiveness levels and competitiveness coefficient.

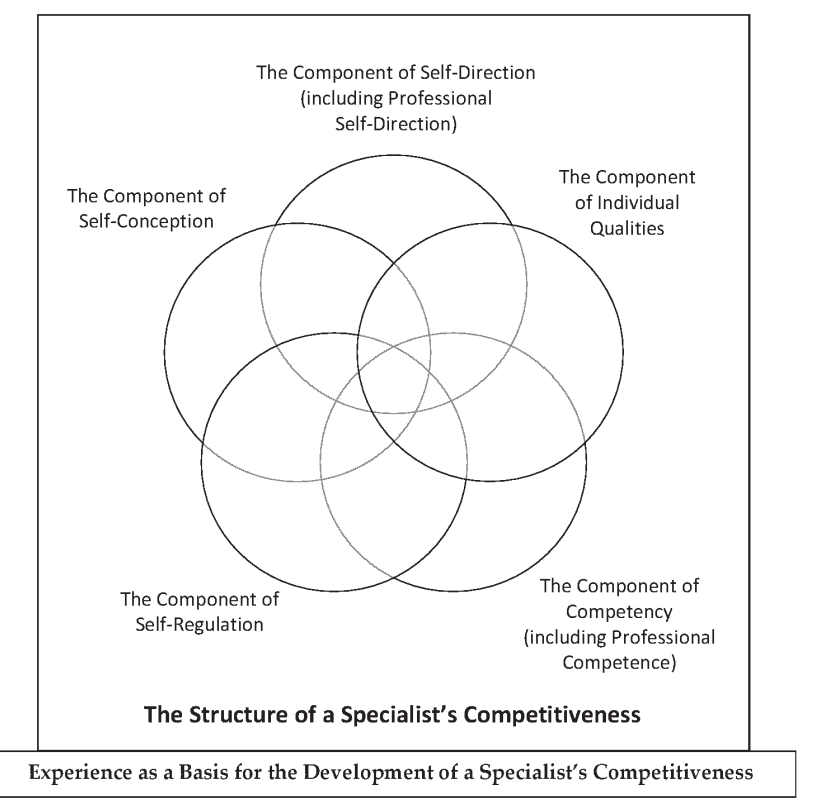

Figure 1. The Structure of specialist's competitiveness (Katane, 2011) 
The elaborated research methodology of competitiveness enables the evaluation of each specialist's competitiveness not only according to 66 indicators, but also to determine each specialist's competitiveness coefficient and competitiveness level according to the scale of levels from 0 to 9 . (Table 1 ).

Table 1

Methodology for the Determination of the Common Level of Competitiveness

\begin{tabular}{lccl}
\hline N & $\begin{array}{c}\text { Level of } \\
\text { Competitiveness }\end{array}$ & $\begin{array}{c}\text { Limits of Obtained } \\
\text { Self-evaluation } \\
\text { Points }\end{array}$ & Level of Competitiveness \\
\hline 1. & 9 & $244-264$ & Very high level \\
\hline 2. & 8 & $222-243$ & High level \\
\hline 3. & 7 & $200-221$ & Relatively high level \\
\hline 4. & 6 & $178-199$ & Level, which is a bit higher than the average level \\
\hline 5. & 5 & $156-177$ & Average level \\
\hline 6. & 4 & $134-155$ & Level, which is a bit lower than the average level \\
\hline 7. & 3 & $111-133$ & Relatively low level \\
\hline 8. & 2 & $89-110$ & Low level \\
\hline 9. & 1 & $67-88$ & Very low level \\
\hline 10. & 0 & $0-66$ & Critical level of competitiveness \\
\hline
\end{tabular}

\section{Results of the 2 nd research stage}

At the research base - enterprise, which is one of the international insurance agencies in Latvia, there are more than 700 employees and 59 branches in Latvia. It is one of the most significant employers of the insurance industry in Latvia. Since the research base enterprise is working on its growth and sustainable development on an ongoing basis, the enterprise management was truly interested in this study.

There were 18 specialists of division Y of X International insurance agency in Latvia involved in the research. The participation was voluntary. The specialists selfevaluated their competitiveness. There were questionnaires given to the research respondents.

There were 66 indicators for the evaluation of competitiveness defined in the questionnaires. The respondents had to evaluate their competitiveness according to each of these indicators in the scale of 4 points. If a respondent fully agreed to the statement, he or she marked the statement with a tick, choosing answer "Yes" in the respective column of the table, which, according to the nominal scale, meant 4 points. If the respondent completely disagreed to the statement, he or she marked the statement with a tick in the column of "No", which in the data processing gave 1 point. Partial agreement to the statement in the nominal scale equalled to 3 points in the nominal scale, whereas partial disagreement - to 2 points. The maximum number of points, which could be obtained by a respondent, was 264 points (in total for the evaluation according to all 66 indicators). Data processing was held in collaboration with programmer Edgars Katans.

For each specialist employed at Y division, who participated in the research, there was determined not only the level of competitiveness, but also the coefficient of competitiveness by dividing the number of obtained points by the maximum number of points, which could be obtained (Table 2). 
Irrespective of the fact that the coefficients of competitiveness determined as result of self-evaluation performed by respondents - specialists of research base enterprise $\mathrm{Y}$ division are relatively high, because they are close to " 1 ", and the levels of specialists' competitiveness are within the range from level 6 to 8 (Table 2 and Table 3), several indicators show that it is necessary to provide assistance.

Table 2

Results of the Evaluation of Insurance X enterprise Y Division Respondents' Competitiveness $\left(N=18 ; n=66 ; \Sigma_{\max }=264\right)$

\begin{tabular}{lcccc}
\hline No & Respondents & $\begin{array}{c}\text { Competitiveness } \\
\text { Evaluation Amount }(\Sigma)\end{array}$ & $\begin{array}{c}\text { Level of } \\
\text { Competitiveness }\end{array}$ & $\begin{array}{c}\text { Coefficient of } \\
\text { Competitiveness }\end{array}$ \\
\hline 1. & A & 209 & 7th level & 0.79 \\
\hline 2. & B & 217 & 7th level & 0.82 \\
\hline 3. & $\mathrm{C}$ & 209 & 7th level & 0.79 \\
\hline 4. & $\mathrm{D}$ & 219 & 7th level & 0.83 \\
\hline 5. & $\mathrm{E}$ & 218 & 7th level & 0.83 \\
\hline 6. & $\mathrm{~F}$ & 233 & 8th level & 0.88 \\
\hline 7. & $\mathrm{G}$ & 223 & 8th level & 0.84 \\
\hline 8. & $\mathrm{H}$ & 191 & 6th level & 0.72 \\
\hline 9. & $\mathrm{I}$ & 227 & 8th level & 0.85 \\
\hline 10. & $\mathrm{~J}$ & 238 & 8th level & 0.90 \\
\hline 11. & $\mathrm{~K}$ & 204 & 7th level & 0.77 \\
\hline 12. & $\mathrm{~L}$ & 222 & 8th level & 0.84 \\
\hline 13. & $\mathrm{M}$ & 216 & 7th level & 0.81 \\
\hline 14. & $\mathrm{~N}$ & 198 & 6th level & 0.75 \\
\hline 15. & $\mathrm{O}$ & 215 & 7th level & 0.81 \\
\hline 16. & $\mathrm{P}$ & 6th level & 0.72 \\
\hline 17. & $\mathrm{R}$ & $\mathrm{S}$ & 6th level & 0.75 \\
\hline 18. & 199 & 6th level & 0.74 \\
\hline
\end{tabular}

Table 3

Proportion Indicators for the Levels of Respondents' Competitiveness in the Sample $(\mathrm{N}=18 ; n=9)$

\begin{tabular}{lccc}
\hline No & $\begin{array}{c}\text { Absolute Number of } \\
\text { Respondents }(\mathrm{N}=18)\end{array}$ & $\begin{array}{c}\text { Proportion of Respondents } \\
\text { in the Sample }(\Sigma=100 \%)\end{array}$ & $\begin{array}{c}\text { Levels of Respondents' } \\
\text { Competitiveness }(\mathrm{n}=9)\end{array}$ \\
\hline 1. & 5 & 28 & 6th level \\
\hline 2. & 8 & 44 & 7 th level \\
\hline 3. & 5 & 28 & 8th level \\
\hline
\end{tabular}

Having analysed and evaluated the obtained results according to the indicators, we drew a conclusion that the highest evaluation was given by respondents to their driver's skills and licence as an indicator of competitiveness, because independence and moving quickly from place to place by means of one's own vehicle ensures their mobility in the labour market, thus adapting to the fast pace of modern society's life, as well as providing a potential perspective to work at several work places, if necessary. 
Alongside the driver's skills and licence, the respondents have given high rating to the several indicators of their competitiveness (Table 4).

The lowest evaluations were received concerning several indicators, which proves that the research participants need assistance regarding the following spheres of competitiveness: public speech and presentation skills; a psychologist shall assist in learning how to manage one's emotions, mood; achievement of planned aims (if it is impossible to achieve the set aims, perhaps, the specialists shall assist in adjusting aims and motivation spheres); flexibility of behaviour and conformity with the particular situation; forecasting skills in relation with critical thinking.

Unfortunately, it is necessary to admit that: 1 ) respondents have relatively low selfconfidence; 2) respondents do not see the opportunities to have professional growth at the research base enterprise, as well as they do not know how to realize it. Most of all the research participants are afraid of making mistakes. When establishing a system for the support and promotion of the development of competitiveness at the enterprise, it would be necessary to assist the specialists from the above mentioned fear through mutual cooperation.

Table 4

Top Rated Competitiveness Indicators $\left(n=18 ; \Sigma_{\max }=72\right)$

\begin{tabular}{|c|c|c|c|}
\hline $\mathrm{N}$ & Indicators & $\begin{array}{l}\text { Sum of Evaluation } \\
\text { Points }(\Sigma)\end{array}$ & $\begin{array}{c}\text { Ranks } \\
(\mathrm{R})\end{array}$ \\
\hline 1. & Driver's skills and licence as an indicator of competitiveness & 71 & 1.5 \\
\hline 2. & $\begin{array}{l}\text { A desire to improve oneself as a personality, including } \\
\text { acquisition of new knowledge, to develop one's skills and } \\
\text { abilities }\end{array}$ & 71 & 1.5 \\
\hline 3. & $\begin{array}{l}\text { I have my own principles, which I try to observe, because } \\
\text { they are grounded on values in my life }\end{array}$ & 68 & 4 \\
\hline 4. & $\begin{array}{l}\text { Readiness to take responsibility for one's words and actions } \\
\text { before oneself and others }\end{array}$ & 68 & 4 \\
\hline 5. & Other people's respect, who can achieve a lot in life & 68 & 4 \\
\hline & $\begin{array}{l}\text { A desire that I would be respected by others, including } \\
\text { colleagues and the management of enterprise }\end{array}$ & 67 & 6.5 \\
\hline & $\begin{array}{l}\text { A desire and striving to achieve success in one's life, } \\
\text { including one's profession }\end{array}$ & 67 & 6.5 \\
\hline 8. & A desire and orientation towards the success in one's life & 65 & 8.5 \\
\hline & $\begin{array}{l}\text { A desire to achieve success, to receive recognition and praise } \\
\text { from others - this enhances self-confidence, creates positive } \\
\text { emotions and inspires starting new activities }\end{array}$ & 65 & 8.5 \\
\hline 10. & A specialist's professional competency & 64 & 10 \\
\hline & $\begin{array}{l}\text { An ability to forecast the events of the nearest future and to } \\
\text { model own behaviour according to the situation }\end{array}$ & 62 & 11.5 \\
\hline & $\begin{array}{l}\text { The ability to develop own career successfully by achieving } \\
\text { high results in any sphere }\end{array}$ & 62 & 11.5 \\
\hline & $\begin{array}{l}\text { I'm not envious and malevolent. I'm glad not only to for my } \\
\text { success, but also for the success of others. }\end{array}$ & 61 & 13.5 \\
\hline & $\begin{array}{l}\text { Readiness to overcome difficulty in order to achieve the } \\
\text { planned }\end{array}$ & 61 & 13.5 \\
\hline
\end{tabular}




\section{Results of the 3rd research stage}

Based on the results, we concluded that it is very necessary to develop and offer our conception for support and promotion of the specialists' competitiveness at the insurance company.

In the first conception design phase, we developed a model (Figure 2 see on next page) with the three main functional areas: personnel management, career counselling and mentoring (Katane, Kristovska \& Katana, 2013; Katane \& Kristovska, 2015a).

Our theoretical base for substantiation of these three functions' groups is the following:

- Career Counselling (Bloch, 2004; Goodman \& Hoppin, 2007; Kuijpers, Schyns \& Scheerens, 2006; Толочек, 2005 etc.);

- Management Sciences, including Personnel Management (Caune, 2005; Dāvidsone, 2008; Forands, 2004; Heathfield, 2015; Kristovska, 2005 etc.);

- Mentoring (Achinstein \& Athanases, 2006; Baltušite, 2013; Daloz, 1986; Fibkins, 2002; Israel, Kamman \& Sindelar, 2014; Katane \& Laizāne, 2012a; Konstantinova \& Rivža, 2007; Marlow, 2009; Raymond \& Kannan, 2014 etc.).

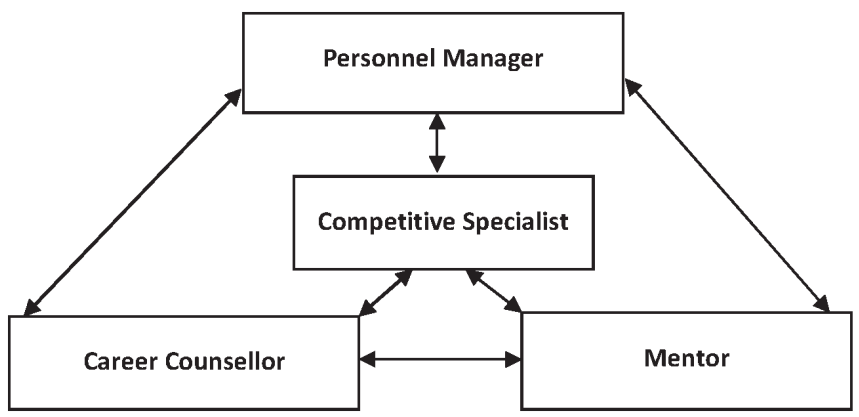

Figure 2. The support and cooperation system at a modern enterprise (Katane \& Kristovska, 2015a; Katane, Kristovska \& Katana, 2013)

The aim of this system is to provide appropriate and friendly environment for the professional development of specialists, therefore the specialist of an enterprise with his/her competitiveness is placed in the centre of the model, that emphasises the aim that directs the functioning of the whole system: to cooperate with each specialist in the enterprise in order to support and promote his/her professional development, including competitiveness' development. The double pointed arrows that can be seen in the model between the components of the system show that in each organisation (enterprise) there must be a cooperation between the representatives of personnel management, career counselling and mentoring, who working as a team can fulfil the main aim of this system of cooperation and perform their functions.

In the second conception design phase, the developed model was assessed by competent experts. To carry out the assessment of the devised model, the following materials were sent for the expert assessment (Katane, 2014a; Katane, Kristovska \& Katane, 2013): 1 ) expert's work sheet; 2) the model (Figure 2). Assessment was carried out without consultations or discussions between the experts. The assessment was made individually, independently and anonymously. Experts assessed the model in the scoring system of 10 points, where " 1 " meant a very low rating, but " 10 " - a very high rating. 
Owing to the assessment method applied by the experts, we obtained results that are integrated in Table 5 and Table 6 (see on the next page). In these tables both the rating given by the experts and descriptive statistics are given. Descriptive statistics of the obtained assessment shows that all experts have given high (8), very high (9) and extremely high rating (10) respectively to each criteria model, and the lowest rating, that was given, were 8 points, but the highest -10 points evaluating 1) both the assessment of each expert; 2) and expert assessments that correspond to each criteria of the assessment. Judging from the sums in the assessments of experts (Table 1), it can be concluded, that the highest ratings were given by experts $\mathrm{D}$ and $\mathrm{F}$, scattering of the ranking in their assessment is - amplitude 0, as all criteria of the model have received the highest rating "10" $(\Sigma=80)$, but expert $G$ has given the lowest rating in comparison to others $(\Sigma=67)$, whose minimum assessment was 8 points (high rating), but the highest rating -9 (very high rating).

Table 5

Results of Expertise

\begin{tabular}{llccccccc}
\hline No & Criteria for Evaluation & \multicolumn{7}{c}{ Evaluations of Experts } \\
\hline & & $\mathrm{A}$ & $\mathrm{B}$ & $\mathrm{C}$ & $\mathrm{D}$ & $\mathrm{E}$ & $\mathrm{F}$ & $\mathrm{G}$ \\
\hline 1. & Criterion A & 10 & 8 & 10 & 10 & 9 & 10 & 9 \\
\hline 2. & Criterion B & 10 & 10 & 10 & 10 & 9 & 10 & 8 \\
\hline 3. & Criterion C & 10 & 10 & 9 & 10 & 8 & 10 & 8 \\
\hline 4. & Criterion D & 9 & 8 & 10 & 10 & 9 & 10 & 9 \\
\hline 5. & Criterion E & 9 & 10 & 9 & 10 & 9 & 10 & 9 \\
\hline 6. & Criterion F & 9 & 10 & 10 & 10 & 8 & 10 & 8 \\
\hline 7. & Criterion G & 8 & 10 & 10 & 10 & 9 & 10 & 8 \\
\hline 8. & Criterion H & 10 & 10 & 10 & 10 & 9 & 10 & 8 \\
\hline & $\Sigma$ & 75 & 76 & 78 & 80 & 70 & 80 & 67 \\
\hline & Min & 9 & 8 & 9 & 10 & 8 & 10 & 8 \\
\hline & Max & 10 & 10 & 10 & 10 & 9 & 10 & 9 \\
\hline & A & 1 & 2 & 1 & 0 & 1 & 0 & 1 \\
\hline & Me & 9.5 & 10 & 10 & 10 & 9 & 10 & 8 \\
\hline & Mo & 10 & 10 & 10 & 10 & 9 & 10 & 8 \\
\hline
\end{tabular}

Table 6

Results of Expertise

\begin{tabular}{llcccccccc}
\hline No & Criteria for Evaluation & $\mathrm{Ev}_{\text {coeff. }}$ & $\mathrm{R}$ & $\mathrm{Min}$ & $\mathrm{Max}$ & $\mathrm{A}$ & $\mathrm{Me}$ & $\mathrm{Mo}$ & $\Sigma$ \\
\hline 1. & Criterion A & 0.94 & 3.5 & 8 & 10 & 2 & 10 & 10 & 66 \\
\hline 2. & Criterion B & 0.96 & 1.5 & 8 & 10 & 2 & 10 & 10 & 67 \\
\hline 3. & Criterion C & 0.93 & 6.5 & 8 & 10 & 2 & 10 & 10 & 65 \\
\hline 4. & Criterion D & 0.93 & 6.5 & 8 & 10 & 2 & 9.5 & 10 & 65 \\
\hline 5. & Criterion E & 0.94 & 3.5 & 9 & 10 & 1 & 9.5 & 10 & 66 \\
\hline 6. & Criterion F & 0.93 & 6.5 & 8 & 10 & 2 & 10 & 10 & 65 \\
\hline 7. & Criterion G & 0.93 & 6.5 & 8 & 10 & 2 & 10 & 10 & 65 \\
\hline 8. & Criterion H & 0.96 & 1.5 & 8 & 10 & 2 & 10 & 10 & 67 \\
\hline
\end{tabular}

Explanation of abbreviations: Min (minimal value), Max (maximal value), A (amplitude), Me (median), Mo (mode), $\Sigma$ (sum of expert evaluations), $\mathrm{Ev}_{\text {coeff. }}$ (evaluation coefficient), $\mathrm{R}$ (rank) 
The values of median and mode show that this expert has mainly given 8 points, the value of amplitude as scattering ratio is " 1 ". Analysing the received expert assessments and viewing the criteria of model assessment (Table 6), it can be concluded that the advantages of the devised model are the following:

- The correspondence of model to the aim of its development, namely, for the support and promotion of organisation's staff competitiveness (Criterion B; $\Sigma=67 ; \Sigma_{\max }=70 ; \mathrm{Ev}_{\text {coeff. }}=0.96$ );

- Real and practical possibility to devise a system for the support of staff competitiveness in an organisation applying this model, and providing cooperation and team-work between specialists of different kinds and levels (Criterion $\mathrm{H}$; $\Sigma=67 ; \Sigma_{\max }=70 ; \mathrm{Ev}_{\text {coeff. }}=0.96$ );

- The universality of the model, namely, wide application in different kinds of organisations (enterprise/institution/different government agencies) for the promotion and support of staff competitiveness (Criterion A; $\Sigma=66 ; \Sigma_{\max }=70$; $\mathrm{Ev}_{\text {coeff. }}=0.94$;

- The scope and sufficiency of personnel management functions, included in the model, (Criterion $\mathrm{E} ; \Sigma=66 ; \Sigma_{\max }=70 ; \mathrm{Ev}_{\text {coeff. }}=0.94$ );

- The relation of model to the theory and practice of management (Criterion C; $\left.\Sigma=65 ; \Sigma_{\max }=70 ; \mathrm{Ev}_{\text {coeff. }}=0.93\right)$;

- The transparency and understandability of the model (Criterion D; $\Sigma=65$; $\Sigma_{\max }=70 ; \mathrm{Ev}_{\text {coeff. }}=0.93$ );

- The scope and sufficiency of career counselling functions included in the model $\left(\right.$ Criterion F; $\Sigma=65 ; \Sigma_{\max }=70 ; \mathrm{Ev}_{\text {coeff. }}=0.93$ );

- The scope and sufficiency of mentoring functions included in the model (Criterion G; $\Sigma=65 ; \Sigma_{\max }=70 ; \mathrm{Ev}_{\text {coeff. }}=0.93$ ).

During the next stage of data processing and the analysis of results, we performed the secondary processing of the data, using Freedman Test (SPSS 17.0 software program). The following data was obtained (Table 7).

Table 7

Results of Friedman test (SPSS 17.0)

\begin{tabular}{lll}
\hline $\mathrm{N}$ & Obtained values & \\
\hline 1 & $\mathrm{~N}$ & 7 \\
\hline 2 & $\chi^{2}$ (Chi-Square) & 3.934 \\
\hline 3 & $\mathrm{df}(\mathrm{n}-1)$ & 7 \\
\hline 4 & Asymp. Sig. & 0.787 \\
\hline
\end{tabular}

As Chi-Square criteria: $\chi^{2}=3.93<\chi_{0.05 ; 7}^{2}=14.07$, but $\mathrm{p}-$ value $=0.787>\alpha=0.05$, then we cann' t deny $\mathrm{H}_{0}$. It can be concluded that there is mutual concord among the experts' evaluations.

In the third conception design phase, the author of this article I. Katane continued to develop and improve model and called it The Model for Development and Promotion of Staff's Competitiveness in Modern Enterprise as Learning Organization (Figure 3).

In the second model version, modern organization is self-developing, self-organising, self-evaluating and open system of business, professional development, professional support and promotion, and also educational environment (Katane, 2014a; Katane, 2014b). 
New theoretical research directions became the methodological base for the model development and improvement (Figure 3):

- Knowledge Society (Bindé, 2005; Gross, 2010; Katane, 2007; Sterling, 2001 etc.);

- Learning Organisation (DeGeus, 1999; Garratt, 2000; Gephart et al, 1996; Katane \& Laizāne, 2012b; Marsick \& Watkins, 1999; Rowe, 2010; Senge, 1990 etc.).

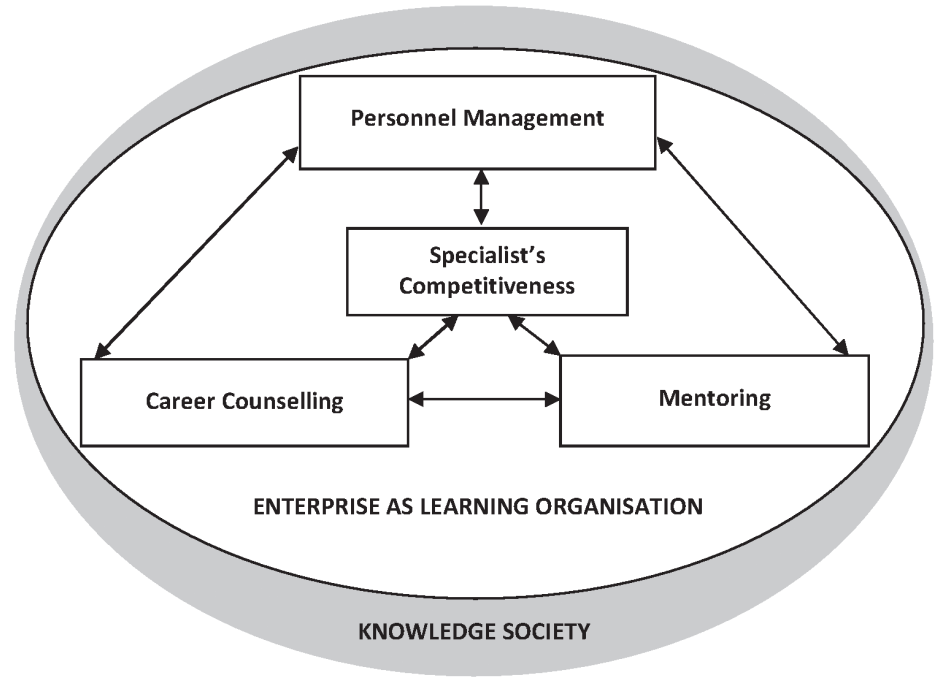

Figure 3. The model of support and promotion system for development of the staff competitiveness in modern enterprise as learning organisation (Katane, 2014a; Katane, 2014b)

In the last conception design phase, the authors of this article added in the model (Figure 4) one more important contemporary organisation function - diagnostics and evaluation of competitiveness and two more contexts: context of sustainable development and context of information and knowledge society.

There were theoretical investigations in the following scientific directions:

- Information Society (Aristovnik, 2014; Eryomin, 1998; Fuchs, 2008; Garnham, 2004; Harvey, 2010; Karnītis, 2004; Katane, Kristovska \& Katans, 2013; Katane, Kristovska \& Katans, 2014; Katans, 2013; Paavola \& Hakkarainen, 2005; Webster, 2002; Webster, 2004 etc.);

- Sustainable Development (Breidlid, 2004; Grabovska, 2006; Katane, 2007; Mebratu, 1998; Miller, 2007; Omann \& Spangenberg, 2002; Salite, 2006; Salite et al, 2005; Salite et al, 2010; Salite \& Pipere, 2006; Sterling, 2002; Witthaus et al, 2010 etc.).

In order to ensure own and whole society's sustainable development the modern enterprise has to become a knowledge organization. It was important to scientifically substantiate a modern enterprise as a knowledge organisation or a learning organisation (Figure 4). 


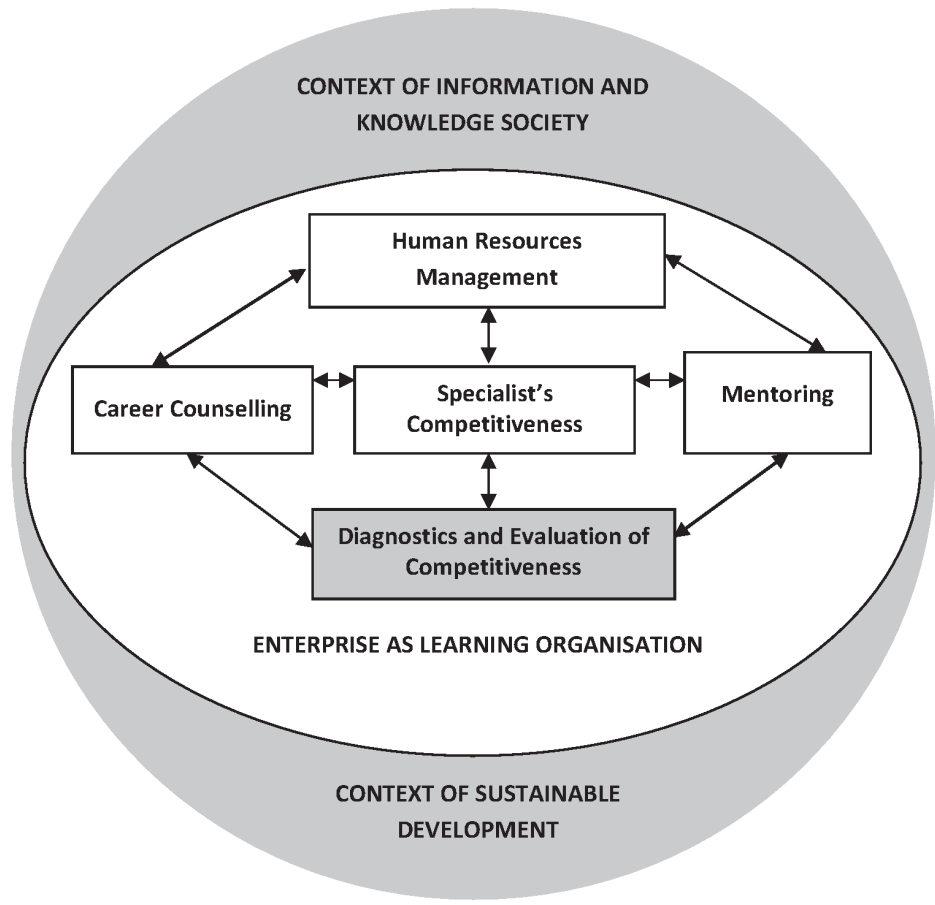

Figure 4. The model for evaluation, support and promotion of the specialist's competitiveness development in modern enterprise as learning organization (Authors' design; adapted, modified and developed from Katane, 2014a; Katane, 2014b; Katane \& Kristovska, 2015a; Katane, Kristovska \& Katana, 2013; Katans, 2013)

\section{Why was it so important?}

The modern enterprise can be friendly and supportive environment for support and promotion of specialists' competitiveness if it becomes learning or knowledge organisation and sustaining. A viable and sustainable system is only a system that is:

- open for new information;

- able to study the processes going on in the surrounding environment, including transformational processes;

- can learn from the own and others experience;

- on the basis of obtained new information and new experience, ready to draw conclusions which are necessary for ensuring its viability and sustainability and ready to change continuously on the basis of these conclusions.

There are important contexts of information and knowledge society and sustainable development (Figure 4).

There have been advantages of viable, sustainable and competitive organisation described in the scientific literature, enabling them to become the learning organisations or knowledge organisations, because there has been studies the experience of such organisations that is popularised in the publications of several scientists. There were seven basic principles identified that enable a enterprise to become a learning organisation: 1) the analysis and evaluation of environment; 2) the vision and aims; 3) cooperation; 4) taking upon the initiative and risks; 5) the control of study process; 6) recognition 
and enhancement; 7) the continuation of professional development. We offer the eighth principle: development and improvement of specialists' competitiveness in the environment of enterprise as knowledge organisation.

In the developed model the concept of information and knowledge society (Figure 4) is a very broad and multidimensional concept that, according to its meaning, is very closely related to ensuring an open and multifunctional social and educational environment, were education is the important means for promotion of society's sustainable development, respecting the interests and needs of whole society and supplying a lifelong and lifewide education for all target groups. The exchange of information and the use of information technologies are important preconditions for enterprise's viability nowadays and sustainability in future which main functions spheres are the following: 1) diagnostics and evaluation; 2) support and promotion of specialists' competitiveness.

The context of sustainable development has two meanings: 1) sustainable development of modern enterprise as learning organisation; 2) sustainable development of environment, including society as social environment.

The sustainability of modern enterprise depends on its competitiveness, but competitiveness of an enterprise to a great extent depends on the competitiveness of each employee as a specialist, therefore it is important to evaluate the specialists' competitiveness and promote its development at modern enterprises.

In our new model design (Figure 5), we show a modern enterprise as learning organization which has already four functional groups: 1) career counselling; 2) human resources management (instead personnel management); 3) mentoring; 4) research of competitiveness (diagnostics and evaluation of specialists' competitiveness), that during mutual interaction create the system of support and promotion for the development of specialist's competitiveness in an enterprise as learning/knowledge organisation in the contexts of information and knowledge society and sustainable development.

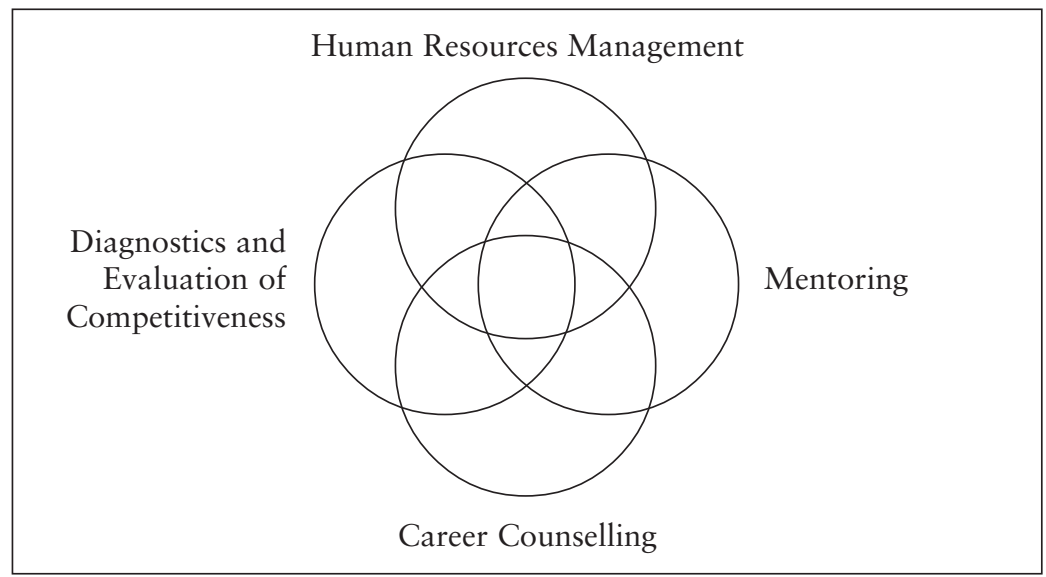

Figure 5. Various functions of modern enterprise as learning organisation for supporting and promoting of the specialists' competitiveness development (Authors' design; modified and developed from Katane, 2014a; Katane, 2014b; Katane \& Kristovska, 2015a; Katane, Kristovska \& Katana, 2013) 
As it can be seen in Figure 5, all functions' groups differ due to the specificity of each sphere, but also mutually complement each other, showing that the functional segments of these spheres partially overlap.

The authors of this article offer to implement their model in any modern organization for promotion not only each specialist's competitiveness development, but also for promotion of own organization's sustainable development.

\section{Discussion and Conclusions}

The dynamics of socio-economic activities update research of human competitiveness in the new context - in the context of sustainable development. Many processes make us question the possibilities of sustainable development and aims of activity. The imperative of today is the sustainable development, including balanced development of the human life wide environment which has various contexts, for example, economic, natural and social environment contexts. Therefore competitiveness has become one of the basic categories not only in economics but also in education sciences. Moreover, personality is defined possessing the ability to become a competitive and respectable personality and a marketable specialist due to characteristic features and competencies acquired during life.

The competitiveness of an enterprise to a great extent depends on the competitiveness of each employee as a specialist, therefore it is important to evaluate the specialists' competitiveness and promote its development at modern enterprises.

Competitiveness is an integrative totality of an individual's qualities (qualities of a personality and a specialist) and functions that ensures its viability, including development and self-actualization, under the conditions of changing environment.

The methodology specially elaborated for the research aim and applied for the evaluation of specialists' competitiveness consists of three parts: 1) a system of various indicators for the evaluation of competitiveness; 2) a questionnaire; as well as 3) a method for the determination of the coefficient of competitiveness and the level of competitiveness. This methodology could be applied for the evaluation of specialists' competitiveness at any enterprise, and it enables to obtain valid and credible results.

The obtained results show that the levels of research base enterprise specialists' competitiveness are within the range of levels 6 to 8 . But the range of the coefficient of competitiveness is from 0.72 to 0.9 . This proves that the specialists employed at the research base insurance enterprise have relatively high self-evaluation level of their competitiveness.

The results of research allowed to find the advantages and disadvantages with regard to the enterprise specialists' competitiveness. However, irrespective of the above mentioned, the methodology for the evaluation of competitiveness enabled to analyse and evaluate in detail the strengths or advantages and the weaknesses or disadvantages of the specialists employed at the enterprise, which identified the problems existing in the sphere of cooperation and mutual relations, as well as in the sphere of career development at the enterprise.

It is necessary to implement and realise authors' conceptual model The Model for Evaluation, Support and Promotion of the Staff's Competitiveness Development in Modern Enterprise as Learning Organization. The modern enterprise can be friendly and supportive environment for promotion of specialists' competitiveness if it becomes 
knowledge organisation and sustaining. Several principles and features of organization testify that it is learning or knowledge organization. There are four functional groups of modern enterprise as learning organization: 1 ) career counselling; 2) human resources management (instead personnel management); 3) mentoring; 4) research of competitiveness (diagnostics and evaluation of specialists' competitiveness), that during mutual interaction create the system of support and promotion for the development of specialist's competitiveness in an enterprise as learning/knowledge organisation in the contexts of information and knowledge society and sustainable development. All functions' groups differ due to the specificity of each sphere, but also mutually complement each other, showing that the functional segments of these spheres partially overlap.

Experts have highly rated the first (initial) version of the model for specialist's competitiveness development, support and promotion in modern enterprise. In all eight criteria of assessment the range of rating was from 8 to 10 points (the highest possible score were 10 points). There is unanimity among expert assessments. The advantages of the devised model are the following: 1) the correspondence of the model to the aim of its development, namely, for the support and promotion of the staff competitiveness; 2) real and practical possibility to devise a system for the support of staff competitiveness in an organization applying this model, and providing cooperation and team-work between specialists of different kinds and levels; 3 ) the universality of the model and wide application in different kinds of organizations and enterprises (enterprise/institution/ different government agencies), the amount of human resource management, career consultation and mentoring functions are sufficient as they uncover the wide spectrum of functions in the support and promotion of staff's competitiveness; 4) the scope and sufficiency of personnel management functions included in the model; 5) the relation of the model to the theory and practice of management; 6) transparency and understand ability of the model; 7) the scope and sufficiency of career counselling functions included in the model; 8) the scope and sufficiency of mentoring functions included in the model.

The development of theoretical substantiation for the conception of support and promotion of staff competitiveness enabled us to conclude that in an enterprise: 1) there must be both research of competitiveness, human resource management, career counselling and mentoring, 2) for creating support team there must be appropriate specialists with research, counselling, pedagogical or mentoring and management competences.

Research, support and promotion of the specialists' competitiveness development is the interaction system which functions in two level contexts: 1) modern enterprise as learning organization; 2) contexts of information and knowledge society, and sustainable development.

\section{References}

Achinstein, B., \& Athanases, S.R. (2006). Mentors in the making. New York: Teachers College Press.

Apressyan, R.G. (1997). Business ethics in Russia. Journal of Business Ethics, 16(14), 1561-1570.

Aristovnik, A. (2014). Development of the information society and its impact on the education sector in the EU: efficiency at the regional (NUTS 2) level. Journal of Educational Technology, 13(2), 54-60. 
Baltušìte, R. (2013). Pedagogiijas studentu gatavība profesionālai darbībai skolas vidē [The pedagogy students' readiness for professional activities in the school environment]. Jelgava: Latvijas Lauksaimniecības universitāte.

Bevan, S., Barber, L., \& Robinson, D. (1997). Keeping the Best: A practical guide to retaining key employees. Institute for employment studies: IES Report 337. Retrieved November 1, 2015, from http://www.employment-studies.co.uk/summary/summary. php?id=337

Bindé, J. et al. (2015). Towards knowledge societies. UNESCO. Retrieved November 1, 2015, from http://unesdoc.unesco.org/images/0014/001418/141843e.pdf

Bloch, D.P. (2004). Spirituality, complexity, and career counseling. Professional School Counseling. USA: ASCA, pp. 343-350.

Breidlid, A. (2004). Sustainable development, indigenous knowledge systems and education in South Africa. Journal for Teacher Education and Training, 4, 3-19.

Caune J. (2005). Konkurētspējīgās priekšrocības radǐšanas, attīstǐšanas un pārnešanas metodika Latvijas uzneemumos. Promocijas darbs [Methodology of creating, developing and transfering of competitive advantage in Latvian companies. Doctoral Thesis]. Rīga: LU.

Covey, S. R. (1990). The 7 habits of highly effective people. USA, New York: The Rockefeller Center, Free Press.

Daloz, L. (1986). Effective teaching and mentoring. San Francisco: Jossey-Bass.

Dāvidsone, G. (2008). Organizāciju efektivitātes modelis [Organizational efficiency model]. Rìga: SIA O.D.A.

DeGeus, A. (1999). The living company. London: Nicholas Brealey Publication.

Dimitrova, P. (2013). A Methodology for a complex assessment of personnel competitiveness within a company. The Economic Archive, 3, 54 -73.

Eryomin, A.L. (1998). Information ecology - a viewpoint. International Journal of Environmental Studies, 54, 241-253.

Fibkins, W.L. (2002). An administrator's quide to better teacher mentoring. Lanham, MD: Scarecrow Press.

Floren, G. L. (1998). Marketable skills and attitudes. California: MiraCosta College. Retrieved September 25, 2014, from http://www.miracosta.edu/home/gfloren/ market.htm\#Careers

Forands, I. (2004). Personāla vadìba [Personnel management]. Rīga: Latvijas izglìtības fonds.

Fuchs, C. (2008). Internet and society: Social theory in the information age. New York: Routledge.

Garnham, N. (2004). Information society theory as ideology. In Webster F. (Ed.). The Information Society Reader. London-New York: Routledge.

Garratt B. (2000). Learning organization: developing democracy at work. Wondon: Harper Collins Business.

Gephart, M.A., Marsick, V.J., Van Buren, M.E., \& Spiro, M.S. (1996). Learning organizations come alive. Training and development, 50, 35-45.

Gnazzo, D.V. (2007). The new world order 21st century. Retrieved September 12, 2015, from http://www.safehaven.com/article/7341/the-new-world-order-21st-century

Gold, J.A., Libby, C.R., Lindner, M.A., Ryckman, R.M., \& Van Den Borne, B. (1997). Values of hypercompetitive and personal development competitive individuals. Journal of Personality Assessment, 69(2), 271-184. 
Goodman, J., \& Hoppin, J. (2007). Adult career counseling: New clients, new strategies (ACAPCD-10). Alexandria, VA: American Counseling Association. Retreived October 18, 2013, from http://counselingoutfitters.com/vistas/ACAPCD/ACAPCD10.pdf.

Grabovska, R. (2006). Ilgtspējības principa ìstenošana skolotāju izglìtībā [Implementation of the principle of sustainability in teacher education]. Daugavpils: DU.

Gross, M. (2010). Ignorance and surprise: Science, society, and ecological design. Cambridge, MA: MIT Press.

Hansen, K. (1998). Dynamic cover letters for new graduates. The 1st edition. Berkeley, California: Ten Speed Press.

Harvey, P.L. (2010). Applying social systems thinking and community informatics thinking in education. In Rudestam, K.E., Schoenholtz-Read, J. (Eds.). Handbook of Online Learning. Thousand Oaks, CA: Sage Publications.

Heathfield, S.M. (2015). Personnel management. Retrieved October 12, 2015, from http://humanresources. about.com/od/HR-Department-Management/g/personnelmanagement.htm.

Israel, M., Kamman, M.L., \& Sindelar, P.T. (2014). Mentoring in action: The interplay among professional assistance, emotional support and evaluation. Exceptional Children, 81(1), 45-63.

Karnītis, E. (2004). Informācijas sabiedrība - Latvijas iespējas un uzdrošināšanās [Information society - Latvian opportunities and boldness]. Rīga: Pētergailis.

Katane, I. (2010). Competitiveness of personality as a new concept in modern education and pedagogy science. In Proceedings of the $9^{\text {th }}$ Interational scientific Conference Engineering for Rural Development, Vol. 9 (May 27-28, 2010). Jelgava: LLU, pp. 327-334.

Katane, I. (2014a). Evaluation of the support and promotion system model for development of the staff's competitiveness in modern enterprise as learning organization. In Proceedings of the 13th International Scientific Conference Engineering for Rural Development, Vol. 13 (May 29-30, 2014, Latvia). Jelgava: LLU TF, pp. 529-534.

Katane, I (2014b). The model of support and promotion system for development of the staff competitiveness in modern enterprise as learning organization. In Proceedings of the International Scientific Conference Society. Integration. Education (May 23-24, 2014, Latvia), Vol. 2. Rēzekne: RA, pp. 95-105.

Katane, I. (2011). Methodological bases for evaluation of specialist competitiveness. In Proceedings of the $10^{\text {th }}$ International Scientific Conference Engineering for Rural Development, Vol. 10 (May 26-27, 2011). Jelgava: LLU, pp. 524-529.

Katane, I. (2007a). No ekoloǵiskās paradigmas lìdz vides modelim izglìtības pètniecībà [From ecological paradigm to environmental model in education research]. Monogrāfisko pētījumu sērija "Izglītības ekologiija” [Monographic study series "Ecology of Education "]. Jelgava, LLU.

Katane I. (2007b). Paradigmas Latvijas izglītības vidē mūsdienās [Paradigms in the Latvian education environment nowadays]. Monogrāfisko pētījumu sērija "Izglītības ekologija” [Monographic study series "Ecology of Education”]. Jelgava: LLU.

Katane, I., \& Kalniņa, I. (2010). Skolēnu personības konkurētspējas attīstība neformālās komercizglìtības vidē (Development of students' personality competitiveness within the environment of non-formal commercial education). Jelgava: LLU. 
Katane, I., \& Kristovska, I. (2015a). Evaluation of specialists' competitiveness in the supportive environment of modern insurance enterprise. In Proceedings of the Scientific International Conference Rural Environment. Education. Personality (May 15-16, 2015, Latvia). Jelgava: LLU TF IMI, pp. 29-41.

Katane, I., \& Kristovska, I. (2015b). Evaluation of the specialists' competitiveness in modern enterprise. In Proceedings of the 14th International Scientific Conference Engineering for Rural Development, Vol. 14 (May 20-22, 2014, Latvia). Jelgava: LLU TF, pp. 713-719.

Katane, I., Kristovska, I., \& Katana, G. (2013). The support and promotion of the staff competitiveness development in modern enterprise. Management of Organizations: Systematic Research, 66, 37-51.

Katane I., Kristovska I., \& Katans E. (2013). Ecological approach in the management of distance education. In Proceedings of the International Scientific Conference Management Horizons in Changing Economic Environment: Visions and Challenges (September 25-27, 2013). Kaunas: Vitautas Magnus University, pp. 395-410.

Katane I., Kristovska I., \& Katans E. (2014). Ecological perspective in analysis and evaluation of specificity of distance education. Environment. In Proceedings of the 7 th International Scientific Conference Rural Environment. Education. Personality (February 7-8, 2014, Latvia). Jelgava: LLU TF IMI, pp. 66-73.

Katane, I., \& Laizāne, A. (2012a). Cross-school mentoring as a facilitator of sustainable development of rural schools in Latvia. In Proceedings of the International Scientific Conference Rural Environment. Education. Personality (March 21-22, 2012). Jelgava: LLU, pp. 43-50.

Katane, I., \& Laizāne, A. (2012b). Divdesmit pirmā gadsimta lauku skolas izglītības vide Latvijā un àrzemēs [Educational environment of the 21st century's rural school in Latvia and abroad]. Monogrāfisko pētījumu sērija "Izglītības ekologiija" [Monographic study series “ Ecology of Education “]. Jelgava: LLU TF IMI. (in Latvian)

Katans E. (2013). Programmètāju profesionālà tālākizglìtība tālmācības vidē [Programmers' professional continuing education in the environment of distance education]. Jelgava: Latvijas Lauksaimniecības universitāte.

Konstantinova, E., \& Rivža, B. (2007). Mentoringa kustības rokasgrāmata [Handbook of merntoring movement]. Jelgava: Latvijas Lauksaimniecības universitāte.

Kristovska, I. (2005). Possibilities of managing distance learning support system in the process of perfecting adult competencies. Riga: University of Latvia.

Kuijpers, M.A.C.T., Schyns, B., \& Scheerens, J. (2006). Career competencies for career success. Journal of Career Development, 32, 303-319.

Li, V. (2011). A Methodology to Assess the Competitiveness of Real Estate Developers in China. A Thesis Submitted for the Degree of PhD. Queensland University of Technology.

Marlow, M. (2009). Supporting teacher professional identity through mentoring activities. Research in Higher Education Journal, Volume 2 (5). Retrieved May 28, 2013, from www.aabri.com

Marsick, V. J., \& Watkins, K.E. (1999). Facilitating learning organizations. Cambridge: University Press.

Mebratu, D. (1998). Sustainability and sustainable development: Historical and conceptual review. Environmental Impact Assessment Review, 18 (6), 493-520. 
Miller, C.A. (2007). Creating indicators of sustainability. Canada, Winnipeg: International Institute for Sustainable Development. Retrieved from: https:/www.iisd.org/ pdf/2007/igsd_creating_indicators.pdf

Omann, I., \& Spangenberg, J. H. (2002). Assessing social sustainability. In Proceedings of the 7th Biennial Conference of the International Society for Ecological Economics (March 6-9, 2002) in Sousse (Tunisia). Retrieved October 10, 2015, from http://seri.at/wp-content/uploads/2010/05/Assessing_social_sustainability.pdf

Otola, I., Ostraszewska, Z., \& Tylec, A. (2013). New directions of development of resource-based view in creating a competitive advantage. Business Management Dynamics, 3 (2), 26-33.

Paavola, S., \& Hakkarainen, K. (2005). The knowledge creation metaphor: An emergent epistemological approach to learning. Science \& Education, 14, 535-557. DOI 10.1007/s11191-004-5157-0

Raymond, B.C., \& Kannan, V., R. (2014). A survey of faculty mentoring programs in AACSB schools of business. Journal of Management Education, 38, 818-842. DOI $10.1177 / 1052562914540456$

Rowe, E. (2010). Looking at extension as a learning organization. Journal of Extension (e-resource), 48 (4). Retrieved October 29, 2015, from http://www.joe.org/joe/2010 august/rb1.php

Salite, I. (2006). Aim of education in the context of present and future educational issues: Perspective of teachers. In A. Pipere (Ed.) Education and Sustainable Development: First Steps toward Changes, Volume 1. Daugavpils: Saule, pp. 390-407.

Salìte, I., Gedžūne, I., \& Gedžūne, G. (2010). From personally relevant experience to action research for sustainable education. In Witthaus M. et al (Eds). Tomorrow Today. Paris: Published by Tudor Rose on behalf of UNESCO, pp. 94-98.

Salite, I., \& Pipere, A. (2006). Aspects of sustainable development from the perspective of teachers. Journal for Teacher Education and Training, 6, 15-32.

Salīte, I., Vanağele, E., \& Jurāne, A. (2005). Organization of learning for sustainable education. Proceedings of the19th international conference ICLORD (April 1822, 2005). Bangkok, pp. 873-881.

Senge, P.M. (1990). The fifth discipline: The art and practice of the learning organization. New York: Doubleday.

Sterling, S. (2002). Sustainable education. Re-visioning learning and change. Schumacher Breifing, No. 6. Publisher by Green Books.

Trunk Širca, N., Nastav, B., Lesjak, D., \& Sulčič, V. (2006). The labour market, graduate competences and study programme development: A case study. Higher Education in Europe, 31(1), 53-64.

Webster, F. (2002). Theories of the information society. Cambridge: Routledge.

Webster, F. (Ed.). (2004). The information society reader. London: Routledge.

Witthaus, M., McCandless, K., \& Lambert, R. (2010). Tomorrow today. Paris: Published by Tudor Rose on behalf of UNESCO.

Андреев, В.И. (2006). Конкурентология [Concurrentology]. Казань: Центр инновационных технологий.

Гарафутдинова, Н.Я. (1998) Конкурентоспособность будущего специалиста высшей квалификации как показатель качества его подготовки [Higher qualification prospective specialist's marketability as a quality indicator of the prepareness]. Вестник Омского университета, (1), 76-78. 
Гриншпун, С.С. (2009). Тест “Самооценка уверенности в себе” [Test "Self-esteem of self-confidence”]. Управление образованием: Внутришкольный контроль [Маnagement of education: Intraschool control]. Retrieved August 11, 2013, from http://www.ucheba.com/met_rus/k_upravobraz/k_vnutrikon/prof_5.htm

Житлухина, Н.Л., \& Алямовская, Н.А. (сост.). (2015). Профессиональное самоопределение [Professional self-determination]. Retrieved March 22, 2014, from http://pandiaweb.ru/text/78/545/63986.php

Митина, Л. М. (2003). Психология развития конкурентоспособной личности [Psychology of the competitive personality's development]. Москва: МПСИ.

Толочек, В.А. (2005). Современная психология труда [Modern labor psychology]. Москва: ПИТЕР.

Тамарская, Н., \& Власова, А. (2002). Подготовка выпускников - будущих педагогов $\kappa$ трудоустройству: тренинг социально-психологической адаптации [Preparing graduates - prospective teachers to employment: Training of social and psychological adjustment]. Калининград: Калининградский государственный университет.

Тараканова, Е.В. (2004). Формирование конкурентоспособности специалиста на этапе профессиональной подготовки [Formation of specialist's marketability during the professional preparation stage]. Retrieved February 27, 2013, from http://journal. seun.ru/J2004_1R/Socio/Tarak.doc

Фетискин, Н.П., Козлов, В.В., \& Мануйлов, Г.М. (2002). Экспресс-диагностика личностной конкурентоспособности [Express diagnostics of personal competitiveness]. Из книги: Фетискин Н.П., Козлов В.В., Мануйлов Г.М. Социальнопсихологическая диагностика развития личности и малых групn [Socio-psychological diagnosis of personality development and small groups]. Москва: Изд-во Института Психотерапии, с. 113-114.

Шаповалов, В.И. (2005). Конкурентоспособность личности в парадигме инновационного педагогического менеджмента [Personality's marketability in the paradigm of innovative pedagogical management]. Ярославский Педагогический Вестник [Journal - Yaroslavl Pedagogical Messenger]. Retrieved March 12, 2013, from http://vestnik.yspu.org/?page=2000_2005

Широбоков, С. (2000). Оценка качества подготовки конкурентоспособного специалиста в России и Соединеннах Штатах Америки [Quality assessment of the education of marketable specialist in Russia and the United States of America]. Материалы конференции Гражданские свободы и образование на рубеже веков и континентов [In Proceedings of the Conference Civil liberties and education at the turn of the century and continents]. Екатеринбург: Екатеринбургское отделение Ассоциации “Профессионалы за сотрудничество” и Уральский филиал Американского совета по международному образованию при финансовой поддержке Бюро по образовательным и культурным программам Госдепартамента США, Россия. Retrieved April 13, 2013, from http://www.prof.msu.ru/publ/conf/ conf46.htm

Correspondence concerning this paper should be addressed to Irena Katane, $\mathrm{PhD}$, Senior Researcher and Associate Professor, Institute of Education and Home Economics at Latvia University of Agriculture, J.Cakstes bulv. 5, Jelgava, Latvia, LV-3001. Email: irena.katane@inbox.lv 